\title{
Has global change induced divergent trends in radial growth of Pinus sylvestris and Pinus halepensis at their bioclimatic limit? The example of the Sainte-Baume forest (south-east France)
}

\author{
Bruno Vila ${ }^{1,2 *}$, Michel VenNeTIER ${ }^{2}$, Christian RIPERT $^{2}$, Olivier ChandiouX $^{2}$, Eryuan LiAnG $^{2,3}$, \\ Frédéric GUIBAL ${ }^{1}$, Franck TORRE ${ }^{1}$ \\ ${ }^{1}$ Institut Méditerranéen d'Écologie et de Paléoécologie, CNRS UMR 6116, Faculté des Sciences et Techniques de Saint-Jérôme, \\ Avenue Escadrille Normandie-Niemen, F-13397 Marseille Cedex 20, France \\ ${ }^{2}$ Cemagref, UR Écosystèmes Méditerranéens et Risques, Groupement d'Aix-en-Provence, Le Tholonet, BP 31, F-13612 Aix-en-Provence, France \\ ${ }^{3}$ Present address: The Institute of Tibetan Plateau Research, Chinese Academy of Sciences, PO Box 2871, Beijing 100085, China
}

(Received 7 March 2008; accepted 27 June 2008)

Keywords:

global change /

bioclimatic limit /

radial growth /

Pinus halepensis /

Pinus sylvestris
Mots-clés :

changement global /

limite bioclimatique /

croissance radiale /

Pinus halepensis /

Pinus sylvestris

\begin{abstract}
- It is agreed that climate (precipitation and temperature) influences the distribution of plant species. Near the margins of a species' natural range, climate becomes limiting to physiological processes. There, climate change may be expected to have a significant impact on tree growth and the species' ranges may be altered.

- In order to assess what influence climate change could exert on the distribution of pine species at their margin, radial growth trends in ring-width chronologies over the last century were analysed. In the French Mediterranean area where climate change is characterized by increased temperature, forest plots were selected along an altitudinal transect on the north-facing slope of the Sainte-Baume mountain (Bouches-du-Rhône, France) where the ranges of Pinus sylvestris and Pinus halepensis overlap.

- Two growth patterns were identified. For P. halepensis, radial growth has increased at all altitudes indicating that climate change has improved growth conditions of this species near the margin of its ecological range. For $P$. sylvestris, radial growth has increased only at low altitudes and even decreased at high altitudes.

- It must be deduced that the growth changes observed cannot be generalised either at the species level or at the geographical level and must be interpreted with great caution.
\end{abstract}

Résumé - Les changements globaux ont-ils induit des tendances de croissance radiale opposées chez Pinus sylvestris et Pinus halepensis à leur limite bioclimatique ? L'exemple de la forêt de la Sainte-Baume.

- Il est admis que les facteurs climatiques (températures et précipitations) sont en partie responsables de la distribution des espèces en limitant leurs processus physiologiques en limite de distribution d'aire. Dans ce cas, les conséquences des changements climatiques sur la croissance sont susceptibles d'y être le plus marqué et leurs distributions pourraient varier.

- Afin d'évaluer les conséquences des changements climatiques, les tendances de croissance observées au siècle dernier dans les séries temporelles de cernes ont été analysées. En zone méditerranéenne française, où les changements climatiques sont caractérisés par une augmentation des températures, des placettes ont été sélectionnées selon un gradient altitudinal sur le flanc nord de la montagne de la Sainte-Baume (Bouches-du-Rhône, France) où les distributions de Pinus sylvestris et Pinus halepensis se superposent.

- Deux patrons de croissance ont été identifiés. La croissance radiale de P. halepensis a augmenté quelle que soit l'altitude considérée indiquant que le changement climatique a amélioré les conditions de croissance de l'espèce à sa limite de distribution. Chez $P$. sylvestris, des tendances de croissance opposées inattendues ont été mises en évidence : la croissance a augmenté à faible altitude et a diminué aux altitudes les plus élevées.

- Il en résulte que les changements de croissance observés ne peuvent être généralisés ni au niveau spécifique ni à une échelle géographique et doivent être interprétés avec la plus grande prudence.

\footnotetext{
*Corresponding author: bruno.vila@univ-provence.fr
} 


\section{INTRODUCTION}

It is generally agreed that climate influences species distribution through the amount of precipitation and temperature. Within the distribution range, growth is often controlled by the length of the active growing season and minimum temperature (IPCC Climate Change, 1995a). Climate change has already induced significant changes in these parameters. During the 20th century, a strong warming trend of $+0.08{ }^{\circ} \mathrm{C}$ $\pm 0.03{ }^{\circ} \mathrm{C}$ per decade has occured. The nine warmest European years have been recorded since 1989 (Luterbacher et al., 2004). In phase with the global trend, European winters have warmed more than summers, resulting in milder winters and decreased seasonal variation (Jones and Moberg, 2003). In Europe, Menzel and Fabian (1999) reported that the average annual growing period has increased by 10.8 days since the early 1960s. In addition, under the impact of climate change, the species' ranges and boundaries have been altered (Chuine and Cour, 1999; Walther et al., 2002; Walther, 2003; Woodward, 1987). But uncertainty surrounds the extent to which climate change may influence species distribution.

Retrospective analyses of tree-ring chronologies are a powerful tool to assess the effects of climate change on tree growth. During the past decades many papers have reported short and long-term increases in radial and height growth for various tree species in several regions of the Northern Hemisphere over the last century (Briffa, 1992; Spiecker et al., 1996). In France, whatever the forest management practice may be, this has been observed for Abies alba Mill. (Becker, 1987; Becker et al., 1994; Bert, 1992a; 1992b), Picea abies (L.) Karst (Becker et al., 1994), Pinus laricio Poir. (Lebourgeois and Becker 1996), Larix decidua Mill. (Belingard and Tessier, 1997), Fagus sylvatica L. (Badeau et al., 1995; Picard, 1995), Quercus pubescens Willd. (Rathgeber et al., 1999), Quercus petraea (Matt.) Liebl.and Quercus robur L. (Bergès et al., 2000; Dhôte et al., 2000).

It is generally accepted that changes in radial growth are related to climate change and to some extent to the rise of temperature, but also to increasing atmospheric $\mathrm{CO}_{2}$, changes in management practices or land-use, fertilization by nitrogen compounds or a combination of these factors (IPCC Climate change 1995a; 1995b; Jarvis, 1998).

The limited number of studies in the Mediterranean area, based either on past growth or on growth modelling under global change, show contradictory results depending on tree species and sometimes within a same species. A few studies have focused on P. halepensis Mill. and P. sylvestris L., two major conifer species in the French Mediterranean zone (Barbéro and Quézel, 1990) whose distribution area is panEuropean for $P$. sylvestris and circum-Mediterranean for $P$. halepensis. These distribution areas overlap along a narrow strip in certain mountains in Provence (southeastern France). There, the limit between these two pine species accurately fits with the limit between the meso-mediterranean and the supra-mediterranean bioclimates (Barbéro et al., 1998; Quézel and Médail, 2003). For Pinus halepensis, Vennetier and Hervé (1999) evidenced trends towards increased height growth. Rathgeber et al. (2005) did not evidence any significant trend in ring-width but found an increase of earlywood density and a decrease of latewood and maximum density. For Pinus sylvestris in the Mediterranean area, decreasing growth trends were predicted, in particular for populations near the limits of its geographical range (Keller et al., 1997; 2000).

Near the centre of its geographical range, climatic factors rarely limit growth except in years of most extreme climate and in the most limiting local situations. Near the margin of its range, a species may develop on a relatively small variety of sites, and climate frequently becomes highly limiting to physiological processes, including growth (Fritts, 1976). In these situations, climate change is likely to have a significant impact on tree growth. In order to assess what influence climate change could have at the margin of species distribution, this article aims at analysing how climate change has influenced radial tree growth during the last century of two pine species, $P$. halepensis and P. sylvestris, growing on the Sainte-Baume mountain (south-east France). For that purpose, we analysed long-term variations in radial tree growth in plots selected along an altitudinal transect near the margin of the $P$. sylvestris geographical range and at the limit of the ecological range of $P$. halepensis. For both species, growth trends were compared for trees growing along an altitudinal cline.

\section{MATERIALS AND METHODS}

\subsection{Study area, experimental design and plots}

The studied area is located on the north-facing slope of SainteBaume Mountain, Bouches-du-Rhône, France (Fig. 1). The experimental design includes six plots for each of the two species (P. halepensis and P. sylvestris) with 108 trees. For P. sylvestris six plots were designated from $\mathrm{S} 1$ to $\mathrm{S} 6$ and for $P$. halepensis from A1 to A6. The average climate is defined as humid Mediterranean with cool winters and warm and dry summers ( 2 to 5 months of drought). The climatic data set collected at Plan d'Aups (altitude $679 \mathrm{~m}$ ) is the most representative of the study sites. Over the last 30 years at Plan d'Aups, the mean annual temperature was $10.3^{\circ} \mathrm{C}$. The mean annual rainfall was $826 \mathrm{~mm}$ but quite irregular (extreme range: $243-1518 \mathrm{~mm}$ ). Extreme climatic events such as severe frosts (minimorum ranged between -10 and $-25{ }^{\circ} \mathrm{C}$ in January or February), scorching heat (maximorum exceeded $38^{\circ} \mathrm{C}$ in July or August) and long droughts (lasting up to 8 months) were recorded during the last century. The climate trends were similar to those evidenced by Lebourgeois et al. (2001) over the last century in France. At the meteorological stations neighbouring the studied plots, minimum temperatures increased by $0.8^{\circ} \mathrm{C}$, maximum temperatures increased by $1.8^{\circ} \mathrm{C}$ whereas no trends in precipitation were observed (calculated as the difference obtained over the 1900-2000 period derived from linear regression with time, Fig. 2).

Tree plots ranged along the altitudinal transect between 350 and $960 \mathrm{~m}$. As temperature decreases with increasing altitude $\left(0.6^{\circ} \mathrm{C}\right.$ per $100 \mathrm{~m}$ ), the difference between the bottom and the top of the mountain is estimated at around $4.2{ }^{\circ} \mathrm{C}$. According to a network of temporary meteorological stations installed in the 1970s, the mean annual rainfall ranges from $850 \mathrm{~mm}$ at the foot of the mountain to $1150 \mathrm{~mm}$ at summit. The upper part of the transect is more windy than the lower part but no wind data were available. 


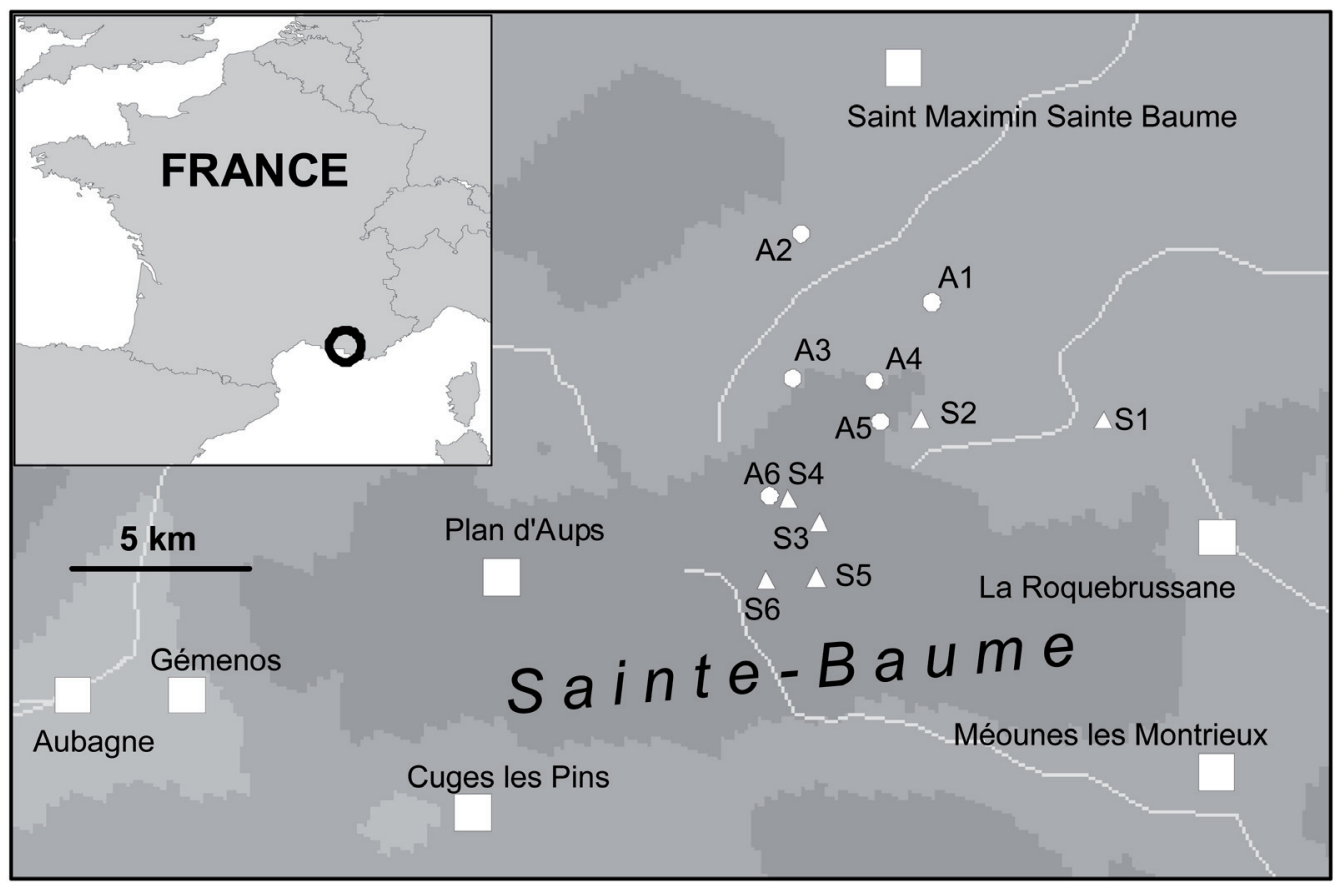

Figure 1. Location of Sainte-Baume Mountain, meteorological stations and sampled plots. Plots of Pinus halepensis ranged from 350 to $690 \mathrm{~m}$ and were designated A1-A6. Plots of Pinus sylvestris ranged from 380 to $960 \mathrm{~m}$ and were designated S1-S6. Variations in grey indicate the relief.

All plots bear soil derived from a calcareous rock layer. They consist of alteritic material covered or not by a colluvial horizon. For each plot, 16 topo-edaphic variables were recorded. Some are reported in Table I. These variables were used to calculate a topo-edaphic index following the methodology developed by Ripert and Vennetier (2005). This topo-edaphic index whose values span the -80 to +80 interval made it possible to sample homogenous plots with medium characteristics $(-80<\mathrm{I}<-20$ : poor topo-edaphic quality, $-20<\mathrm{I}<$ +30 : medium topo-edaphic quality, I $>+30$ : excellent topo-edaphic quality).

\subsection{Sample preparation, ring series and standardization}

For each species, 2-3 groups of 15 trees were sampled along the altitudinal transect. Besides this standard sample depth for dendrochronology studies (Fritts, 1976), 3-4 other intermediate groups of 5 trees for each species were sampled in order to strengthen the transect. In order to reduce bias due to possible change of tree status over time (Cherubini et al., 1998), we selected only dominant trees assuming that the social ranking remained stable over time (Dhôte et al., 2000). According to local forestry records, the forest stands were unmanaged and no thinning or logging was done at least during the last fifty years.

Three cores per tree were collected. Cores were polished using successively finer grits of sand paper then cross-dated by means of skeleton-plot established under a binocular microscope (Stokes and Smiley, 1968). No particular intra-annual density fluctuation, conspicuous enough to disturb skeleton plot process, was noticed (Campelo et al., 2006). Each core was then measured using an Eklund measuring device (precision 1/100 mm). To check cross-dating and possible errors during the measurement, ring-width plots were visually compared and finally cores from the same tree were averaged to obtain a mean individual chronology for each tree (Fritts, 1976). Visual cross-dating was done between trees and some trees that did not crossdate were discarded.

To study growth trends, ring-width series were transformed into basal area increment $\left(\mathrm{mm}^{2}\right)$ series using PPPhalos software (http:// www.imep-cnrs.com/) developed by Guiot and Goeury (1996). This transformation removes the geometric effect that links ring-width to diameter increment (Rathgeber et al., 1999).

Because growth trends also vary with tree age (i.e. increasing in the juvenile phase, stabilizing in the mature phase and decreasing in the senescent phase), data were also indexed to remove age effect by means of a Regional Curve Standardization (RCS; Esper et al., 2003). The Regional Curve (RC) was built for each species by ranking basal area series according to cambial age on trees from a wide ecological range and a wide range of tree age classes. These basal area series were averaged according to cambial age to build up the RC. RCS assumes that such "age-ranked" time series collectively describe the functional form of the overall, age-related, growth trend typical for the species, in a given region (Esper et al., 2003). Because all the sampled trees were unevenly aged (20 to 140 years), rings of a given cambial age formed in different calendar years under various ecological and meteorological conditions were averaged. The mean basal area for each cambial age can therefore be considered as representative of the biological growth of the species, because effects of various climatic and site conditions were cancelled out by the large sample size (Dhôte et al., 2000; Esper et al., 2003). To build the RCS, data from the French Mediterranean region stored in the tree-ring database of the Mediterranean Institute of Ecology and Paleoecology (http:// www.imep-cnrs.com/) and data collected in our study were used (i.e., 

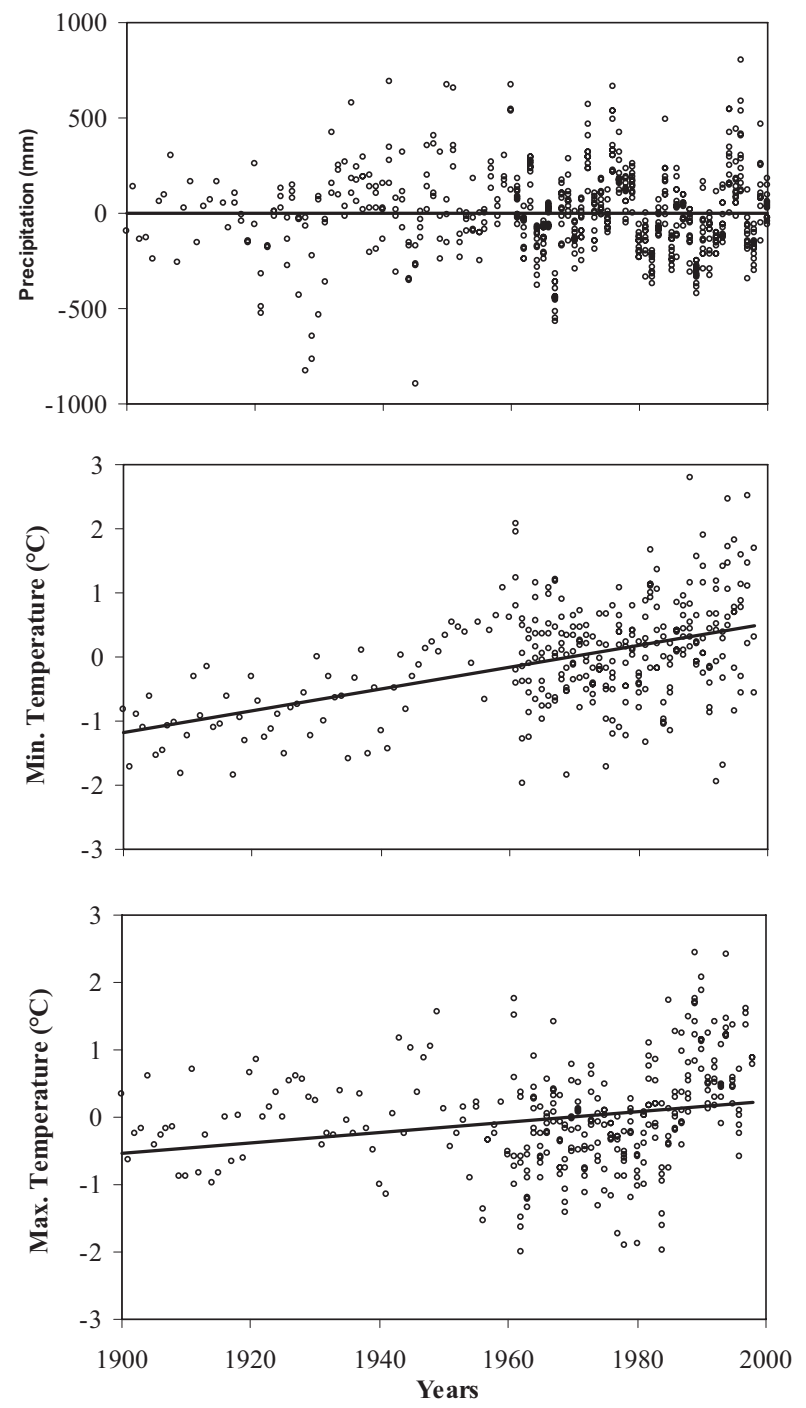

Figure 2. Climate trends in the studied area during the last decades. Anomalies of minimum temperatures, maximum temperatures and rainfall in the annual data were fitted with linear regressions. Temperature changes were statistically significant at the $P<0.001$ level, whereas rainfall changes were not significant. Maximum and minimum temperatures involved the meteorological stations of Marseille, Plan d'Aups, Brignoles, Aubagne, Gémenos, Méounes-lesMontrieux et Roquefort-la-Bédoule and the rainfall involved the meteorological stations of Marseille, Plan d'Aups, Aubagne, SaintMaximin-la-Sainte-Baume, Brignoles, Barjols, Trets, Cuge-les-Pins, Gémenos, Méounes-les-Montrieux, La Roquebrussane et Roquefortla-Bédoule.

537 P. sylvestris and 330 P. halepensis trees). Indexation was done by dividing basal area increment series by the RC which was adjusted by a rectangular hyperbola equation: $A_{R C}=\left(G_{\max } \times C A\right) /\left(t_{0.5}+C A\right)$ where $A_{R C}$ is the adjusted $R C, G_{\max }$ is the maximum basal area increment, $C A$ is the cambial age and $t_{0.5}$ is the cambial age at $0.5 G_{\max }$. This function is well known as the Michaelis-Menten equation for which an exact parameter estimation procedure has been proposed
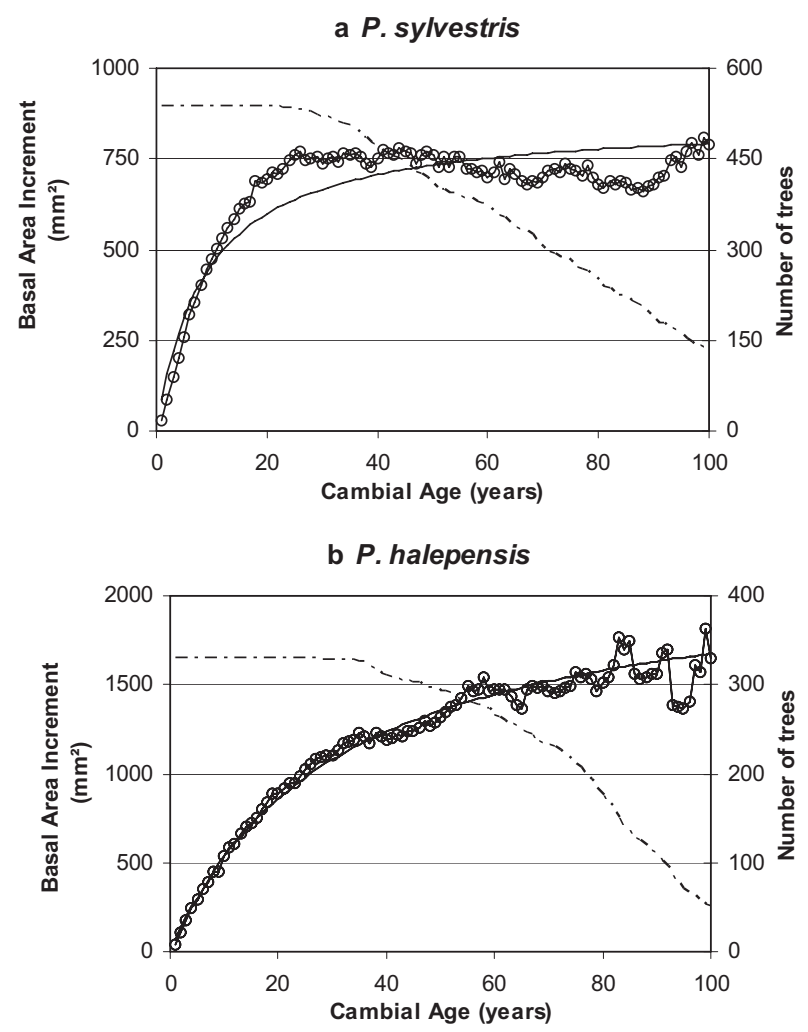

Figure 3. Regional Curve Standardization (RCS) for radial growth of (a) P. sylvestris and (b) P. halepensis in the French Mediterranean region. Solid lines indicate the RCS (basal area increment in $\mathrm{mm}^{2}$ ) and small dots indicate sample depth.

by Mackenzie (2005). For each species, the $R C$ and the number of trees used to build the RC are plotted in Figure 3.

After standardisation by applying the $R C$, at each plot, annual trends were analysed using simple linear regression. The goodness of the fit was tested by classical analyses of variance (Fisher F-test). Slopes were calculated. R software was used for statistical analyses. The regression enabled us to compare growth trends along the altitudinal transect over the last century.

\section{RESULTS}

In the case of $P$. sylvestris, trends in radial growth over time were evidenced in all plots (except plot 6 at $960 \mathrm{~m}$ ) but these trends were variable and became either negligible or even negative at the highest altitude (F-test, $P<0.001$; Fig. 4). Slopes varied between $-1.710^{-2}$ and $8.410^{-3}$. Two groups of plots were identified: tree growth increase $(P<0.001)$ at plots S1, S2 and S3; tree growth decrease at plots S4 and S5 $(P<0.001)$ whereas no significant trend was evidenced for plot S6 $(P=0.26)$.

In the case of $P$. halepensis, whatever the plot, tree growth increase significantly $(P<0.001$; Fig. 5). Slopes varied between $4.910^{-3}$ and $2.910^{-2}$. At plots A2 and A4, tree growth increase moderately. 
Table I. Descriptions of the sites were $P$. sylvestris and $P$. halepensis were sampled along an altitudinal cline in the Sainte-Baume range in Southern France.

\begin{tabular}{|c|c|c|c|c|c|c|c|c|c|c|c|c|c|}
\hline \multirow[t]{2}{*}{ Species } & \multirow{2}{*}{$\begin{array}{c}\text { Plot } \\
\text { name }\end{array}$} & \multirow{2}{*}{$\begin{array}{l}\text { Altitude } \\
\text { (m) }\end{array}$} & \multirow{2}{*}{$\begin{array}{l}\text { Slopes } \\
\left({ }^{\circ}\right)\end{array}$} & \multirow{2}{*}{$\begin{array}{l}\text { Exposition } \\
\text { (Gr) }\end{array}$} & \multirow{2}{*}{$\begin{array}{c}\text { Number } \\
\text { of trees }\end{array}$} & \multirow{2}{*}{$\begin{array}{l}\text { Age (mean } \\
\pm \text { std error) }\end{array}$} & \multirow{2}{*}{$\begin{array}{l}\text { Soil depth } \\
\text { (cm) }\end{array}$} & \multirow[t]{2}{*}{ Type } & \multicolumn{3}{|c|}{ Texture } & \multirow{2}{*}{$\begin{array}{l}\text { Water reserve } \\
(\mathrm{mm} / \mathrm{cm})\end{array}$} & \multirow{2}{*}{$\begin{array}{l}\text { Topo-edaphic } \\
\text { index }\end{array}$} \\
\hline & & & & & & & & & Sand & Loan & Clay & & \\
\hline P. sylvestris & S1 & 380 & 20 & 0 & 15 & $88.1 \pm 20.1$ & $>100$ & Colluvium & 1 & 1 & 1 & $1.70-1.95$ & 24 \\
\hline P. sylvestris & S2 & 480 & 28 & 395 & 5 & $82.8 \pm 25.2$ & $25-45$ & Colluvium & 0 & 2 & 1 & $1.70-1.95$ & 3 \\
\hline P. sylvestris & S3 & 660 & 22 & 342 & 14 & $79.7 \pm 20.0$ & $>100$ & Colluvium & 2 & 0 & 1 & $1.35-1.60$ & 30 \\
\hline P. sylvestris & S4 & 690 & 5 & 305 & 5 & $96.2 \pm 6.3$ & $>100$ & Alterit & 0 & 2 & 1 & $1.70-1.95$ & 17 \\
\hline P. sylvestris & S5 & 875 & 20 & 400 & 13 & $99.1 \pm 19.5$ & $50-75$ & Alterit & 0 & 1 & 2 & $1.70-1.95$ & -12 \\
\hline P. sylvestris & S6 & 960 & 19 & 20 & 5 & $63.2 \pm 1.80$ & $75-100$ & Colluvium & 0 & 1 & 2 & $1.70-1.95$ & 12 \\
\hline P. halepensis & A1 & 350 & 8 & 110 & 5 & $78 \pm 17.8$ & $75-100$ & Colluvium / lapiaz & 0 & 1 & 1 & $1.70-1.95$ & -15 \\
\hline P. halepensis & A 2 & 370 & 6 & 3 & 15 & $80.9 \pm 13.5$ & $50-75$ & Alterit & 0 & 2 & 1 & $1.70-1.95$ & 6 \\
\hline P. halepensis & A3 & 390 & 13 & 25 & 5 & $73.4 \pm 19.1$ & $50-75$ & Colluvium & 0 & 1 & 2 & $1.70-1.95$ & 5 \\
\hline P. halepensis & A4 & 480 & 10 & 10 & 16 & $66.1 \pm 12.3$ & $50-75$ & Colluvium & 0 & 2 & 0 & $1.35-1.60$ & 3 \\
\hline P. halepensis & A5 & 540 & 10 & 30 & 6 & $65.2 \pm 7.1$ & $75-100$ & Colluvium & 2 & 0 & 0 & $\leq 0.7$ & -7 \\
\hline P. halepensis & A6 & 690 & 5 & 345 & 4 & $85.0 \pm 11.7$ & $50-75$ & Colluvium & 0 & 2 & 0 & $1.35-1.60$ & 17 \\
\hline
\end{tabular}
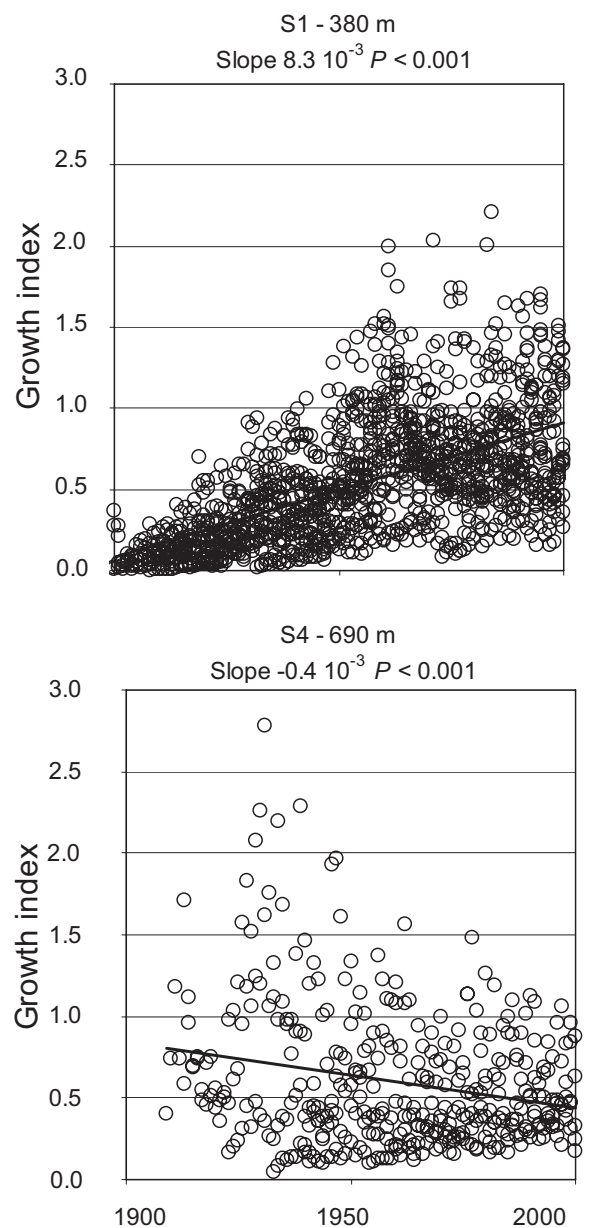
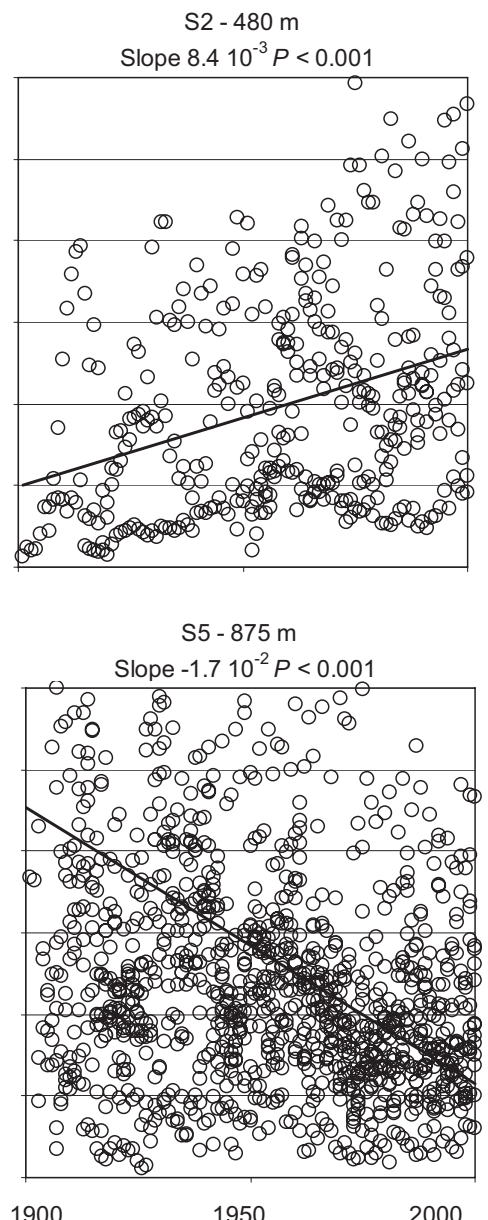

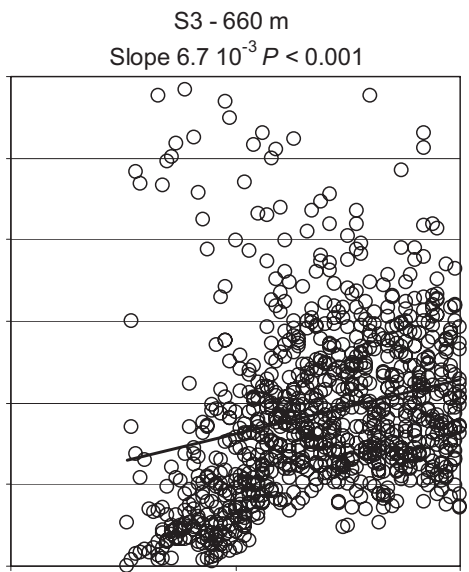

S6 - $960 \mathrm{~m}$

Slope $-1.610^{-3} P<0.001$

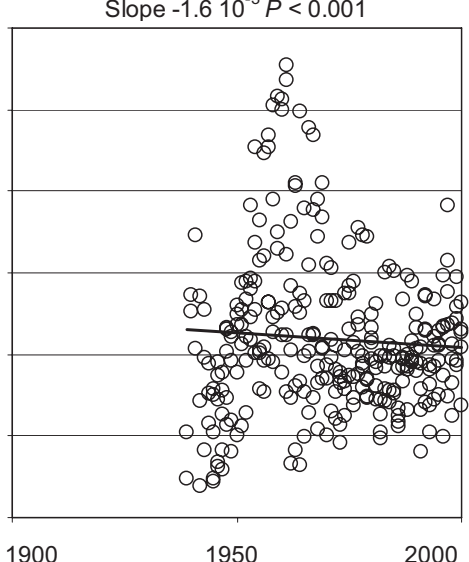

Figure 4. Tree ring increment indexes as a function of time for $P$. sylvestris growing in 6 plots located along an altitudinal cline in the Sainte-Baume range, southern France. Slopes of the linear regressions as well as the corresponding probabilities are indicated. 

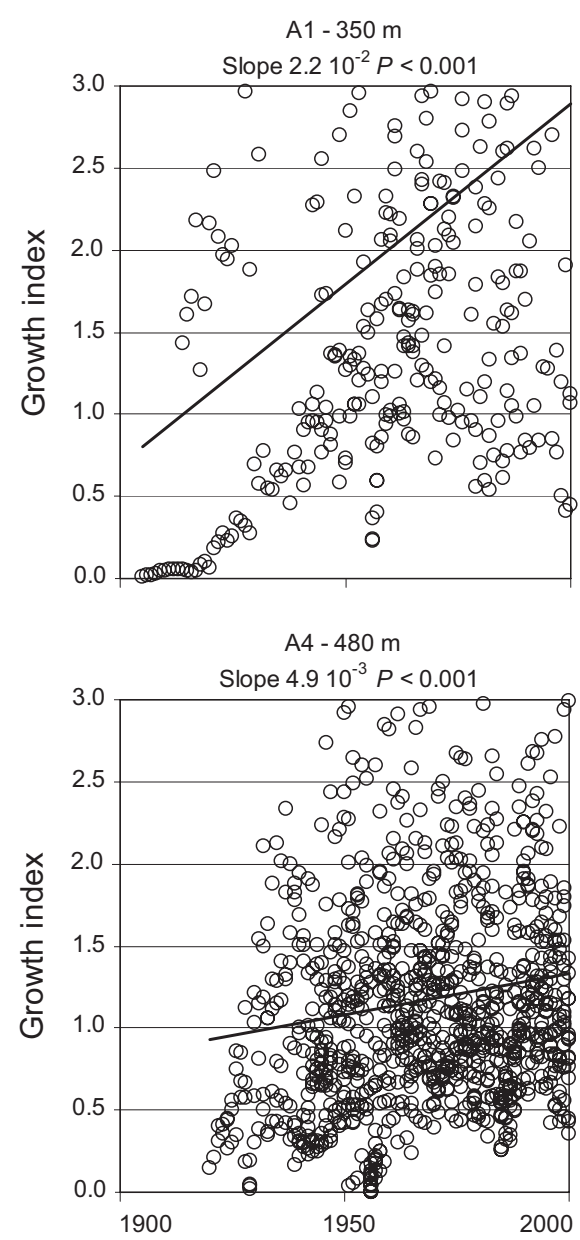
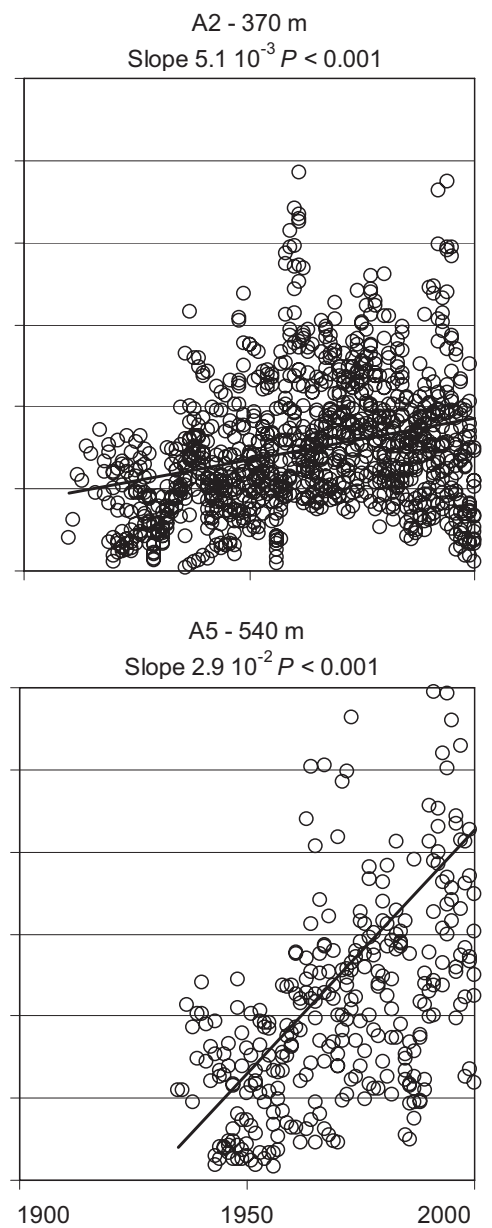
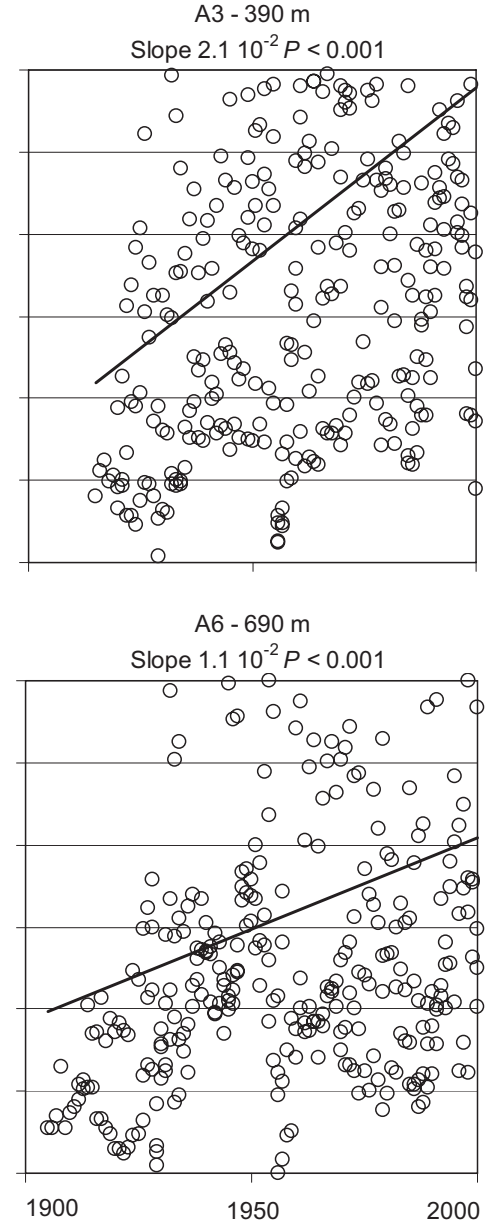

Figure 5. Tree ring increment indexes as a function of time for $P$. halepensis growing in 6 plots located along an altitudinal cline in the Sainte-Baume range, southern France. Slopes of the linear regressions as well as the corresponding probabilities are indicated.

\section{DISCUSSION}

Trends in radial growth have largely been attributed to changes in environment and climate, but could also be due to sampling procedure or to other processes. We examine below possible biases that could have affected our data set.

A possible source of bias involves the sample structure and ecological diversity of the study sites. It is likely that older trees growing in the most unfavourable sites show low growth rates, overestimating radial growth trends. In fact, to build up the $R C$, different age classes were used from several ecological and bioclimatic conditions that guarantee that each species $R C$ describes a regional age-related growth trend. Moreover, at the Sainte-Baume mountain, we aimed to minimise as far as possible age differences and site differences, all the plots being characterised by a medium topo-edaphic index.

Within each plot, another bias could result from selective tree sampling. In natural stands where competition could play a significant role, a bias could be that dominant trees sampled at the present time may have been non-dominant in the past. This biais is unlikely because the social ranking is strongly conserved in pine stands (Dhôte et al., 2000). Changes in forest management practices, with stronger and repeated thinning in the young forest stands, could also be responsible for higher radial growth of the dominant trees but this hypothesis cannot apply to our study sites which have not been logged for several decades.

Last, another bias could involve standardisation techniques. Ring-width decreases as tree age increases mainly for geometrical reasons (Bergès et al., 2000) but standardisation was processed by calculating basal area increments. A bias could occur for P. sylvestris for which mean growth was slightly underestimated between 10 and 40 years and slightly overestimated between 70 and 100 years. Underestimation may create a positive trend; conversely, overestimation may create a negative trend.

Overall, none of these biases can explain the trends observed.

Some environmental factors such as increasing temperature, increased $\mathrm{CO}_{2}$ concentration and increased nitrogen deposition or a combination of these factors may play a role in recent changes observed in radial increment. 


\subsection{Atmospheric $\mathrm{CO}_{2}$ increase}

Many studies attribute positive trends in radial increment to fertilisation by atmospheric $\mathrm{CO}_{2}$ enrichment (Graybill and Idso, 1993; Kienast and Luxmoore, 1988; LaMarche et al., 1984; Rathgeber et al., 2000). Experimental studies with enhanced $\mathrm{CO}_{2}$-concentration on tree seedlings and saplings report stem growth stimulation in the first years of the experiment followed by stabilised growth in the next years (Dobbertin, 2005; Kilpeläinen et al., 2003). Studies on mature trees, either in field experiments or next to natural $\mathrm{CO}_{2}$ springs, suggest either a response to $\mathrm{CO}_{2}$ in stem growth only in young trees or no response at all (Dobbertin, 2005). By using a biogeochemistry model to simulate forest productivity, Rathgeber et al. (2003) showed synergy between climate effect and $\mathrm{CO}_{2}$ increase. If one accepts that a fertilising effect of $\mathrm{CO}_{2}$ might occur, that alone could explain positive trends and balance the negative trends observed on some $P$. sylvestris plots. Given that the fertilising effect of $\mathrm{CO}_{2}$ has a similar impact on all plots, that would not change the responses observed in the different plots. It may be concluded that species and plots react differently according to altitude whatever $\mathrm{CO}_{2}$ concentration may be.

\section{2. $N$-deposition}

Nitrogen is a limiting factor for forest growth. Airborne nitrogen comes from agricultural fertilizers, vehicle exhaust and sewage treatment plants. Nitrogen deposition has increased in some industrialised and agro-industrial areas by up to 50 times the natural background and the global annual release of human-derived soluble nitrogen already exceeds annual natural nitrogen fixation (Vitousek et al., 1997). Nevertheless this impact is region-specific and it is not reported to be particularly strong in southern Provence or in the Sainte-Baume mountain area (INERIS, 2004). Given that nitrogen deposition might be expected to occur in the same way in all plots, it cannot be responsible for differences observed between plots or between species.

\subsection{Climate change}

Although fertilising effects of $\mathrm{CO}_{2}$ and nitrogen deposition cannot be altogether ruled out, their impact cannot be as consistent as that of climatic factors.

Previous dendroecological studies addressing tree-ring to climate relationships revealed that, at Sainte-Baume mountain, $P$. sylvestris growth exhibits a positive response to precipitation from April to September. Regarding the temperature effects, ring width exhibits a negative response to maximum and mean temperatures particularly in May, June and July (Tessier, 1984; 1986). The relationship with temperature is positive in April and September. These results are consistent with the general pattern of the annual growth of conifers in low latitudes or altitudes which focus the major role of spring and summer water balance in determining radial growth rates (Lebourgeois,
2007). For P. halepensis, autumn (November-December) of the previous year and spring (April-May) precipitation plays a key role in ring-width: a positive relationship was found by Serre-Bachet (1982) and Nicault (1999) between these parameters and ring-width. Winter temperatures also positively influence ring-width.

But changes in climatic parameters were recorded and trends were observed over the last decades. In France between 1956 and 1997, seasonal and monthly climate changes were observed and characterized by increases (i) in minimum temperature of about $1.6^{\circ} \mathrm{C}$ in summer and about $1.9^{\circ} \mathrm{C}$ in winter, (ii) in maximum temperature of about $1.8^{\circ} \mathrm{C}$ in summer and about $2.0{ }^{\circ} \mathrm{C}$ in winter and (iii) of $1.2{ }^{\circ} \mathrm{C}$ for the year. A frequent increase in the number of warm days $\left(T_{\text {moy }}>5{ }^{\circ} \mathrm{C}\right)$ in autumn and winter and a slighter decrease in frosty days $\left(\mathrm{T}_{\min }<0{ }^{\circ} \mathrm{C}\right)$ were also recorded. A weak trend in precipitation and a higher frequency of change for rainless days (decreasing in spring and autumn) were observed (Lebourgeois et al., 2001). At the meteorological stations near Sainte-Baume mountain, similar trends were observed. The increase of minimum temperatures is similar to that of an altitudinal shift of $133 \mathrm{~m}$ whereas the increase of maximum temperatures is similar to that of an altitudinal shift of $300 \mathrm{~m}$ evidencing that climate also changed along the altitudinal transect.

Such changes have influenced both species' radial growth but in different ways. P. sylvestris and P. halepensis differ in their long-term trends over the last century. The latter always shows positive growth trends while the former shows divergent trends according to altitude.

For $P$. sylvestris, the response pattern is complex and it varies with altitude. In the study sites, where climate change has worsened growth conditions by increasing both summer temperature and drought, to which the species is sensitive, the increased growth observed in trees below $700 \mathrm{~m}$ at their bioclimatic limit is unexpected. The recent rise of spring minimum and maximum temperatures may help trees below $700 \mathrm{~m}$ to benefit from the water reserve stored during previous autumn and winter. At higher altitude the decreased growth observed may be related to wind acting as an additional desiccating factor, which may increase the effects of drought and solar radiation (Telewski, 1995). At high altitude, our results are consistent with those obtained by Keller et al. $(1997,2000)$ who predicted a decrease of radial growth of $P$. sylvestris by using a ring-width to climate statistical model and a $2 \times \mathrm{CO}_{2}$ scenario.

For $P$. halepensis, the increase of minimum temperatures in January and February and that of temperatures from March to June helps trees to take advantage of the amount of water stored in the soil during winter. Warmer autumns favour a significant second growth period after summer drought (Picard, 1995). The absence of reaction of $P$. halepensis to water deficit and maximum temperatures during summer drought depends on a strategy in which trees elude unfavourable conditions by stopping growth and closing stomata (Aussenac and Valette, 1982; Serre, 1976). Only positive trends were observed in radial increment at all altitudes. These results are consistent with those obtained by Vennetier and Hervé (1999) who evidenced increases in height growth. Rathgeber et al. (2005) found that there was no growth trend for $P$. halepensis but these authors 
worked on short ring series (1950-1999 without years 19561959) collected from a large geographical area and addressed variables other than ring-width. It seems that for P. halepensis, although warming has shifted values of limiting factors, they remain within the range that trees can withstand. The positive growth trend whatever the altitude considered could be attributed to the extension of the growing period.

\section{CONCLUSION}

This study has documented different long-term variations over the last century for two species growing in the same forests in the south-east of France. On the one hand, $P$. halepensis shows a growth increase at any altitude. On the other hand, $P$. sylvestris displayed divergent growth trends depending on altitude. These contrasting trends are all the more remarkable as growth decrease involves plots which were expected to react positively to warming. This study suggests that the extent of tree growth change due to changes in environmental conditions must be interpreted with great caution and from a long term perspective. Although it is not easy to relate long-term variations in tree growth to possible variation of species distribution, it must be reported that a current extension of the range of $P$. halepensis at altitude is noticeable in the Sainte-Baume Mountain area: some isolated pioneer trees (30 years old) are growing up to $1000 \mathrm{~m}$ on the south ridge, far above the theoretical limit of around 700-800 m estimated a few decades ago for this species (Quézel and Médail, 2003). Extending such analyses on the Sainte-Baume Mountain to plots under other edaphic conditions and to other massifs in the French Mediterranean area could provide new information regarding the balance between the two pine species at their bioclimatic limit in the context of climate changes.

Acknowledgements: This study was funded by the Public Interest Group (GIP) on Forest Ecosystems (Ecofor), the Provence-AlpesCôte d'Azur Region and Cemagref. The authors are indebted to many private owners who gave us permission to work in their forests. Roland Estève and Raphaël Manlay contributed much to field work. Jean-Louis Edouard facilitated access to the IMEP database that was helpful for establishing the RC for standardisation. Authors are also grateful to Thomas Curt, Bernard Prévosto, Cathy Fernandez and the anonymous reviewers.

\section{REFERENCES}

Aussenac G. and Valette J.-C., 1982. Comportement hydrique estival de Cedrus atlantica Manetti, Quercus ilex L. et Quercus pubescens Willd. et de divers pins dans le Mont-Ventoux, Ann. Sci. For. 39, $41-62$.

Badeau V., Dupouey J.L., Becker M., and Picard J.F., 1995. Long-term growth trends of Fagus sylvatica L. in northeastern France. A comparison between high and low density stands, Acta Oecol. 16: 571583.

Barbéro M. and Quézel P., 1990. La déprise rurale et ses effets sur les superficies forestières dans la région Provence-Alpes-Côte d'Azur, Bull. Soc. Linn. Prov. 41: 77-88.
Barbéro M., Loisel R., Quézel P., Richardson D.M., and Romane F., 1998. Pines of the Mediterranean basin. In: Richardson D.M. (Ed.), Ecology and biogeography of Pinus, Cambridge University Press, Cambridge, pp. 153-170.

Becker M., 1987. Bilan de santé actuel et rétrospectif du sapin (Abies alba Mill.) dans les Vosges. Étude écologique et dendrochronologique, Ann. Sci. For. 44: 379-402.

Becker M., Bert G.D., Bouchon J., Picard J.F., and Ulrich E., 1994. Tendances à long terme observées dans la croissance de divers feuillus et résineux du Nord-Est de la France depuis le milieu du $19^{\mathrm{e}}$ siècle, Rev. For. Fr. XLVI-4: 335-341.

Belingard C. and Tessier L., 1997. Étude dendrochronologique comparée de vieux peuplements de Larix decidua Mill. dans les Alpes françaises du sud. Dendrochronologia 11: 69-78.

Bergès L., Dupouey J.L., and Franc, A., 2000. Long-term changes in wood density and radial growth of Quercus petraea Liebl. in northern France since the middle of the nineteenth century, Trees- Struct. Funct. 14: 398-408.

Bert G.D., 1992a. Influence du climat, des facteurs stationnels et de la pollution sur la croissance et l'état sanitaire du sapin pectiné (Abies alba Mill.) dans le Jura. Étude phytoécologique et dendrochronologique, Thèse de Doctorat, Université Henri-Poincaré, Nancy, 200 p.

Bert D., 1992b. Silver fir (Abies alba Mill.) shows an increasing longterm trend in the Jura mountains. Lunqua Report 34: 27-29.

Briffa K.R., 1992. Increasing productivity of natural growth conifers in Europe over the last century, Lunqua Report 34: 64-71.

Campelo F., Nabais C., Freitas H., and Gutiérrez E., 2006. Climatic significance of tree-ring width and intra-annual density fluctuations in Pinus pinea from a dry Mediterranean area in Portugal. Ann. For. Sci. 64: 229-238.

Cherubini P., Dobbertin M., and Innes J.L., 1998. Potential sampling bias in long-term forest growth trends reconstructed from tree-rings: a case study from the Italian Alps, For. Ecol. Manage. 109: 103-118.

Chuine I. and Cour P., 1999. Climatic determinants of budburst seasonality of temperate-zone trees. New Phytol. 143: 339-349.

Dhôte J.F., Dupouey J.L., and Bergès L., 2000. Modifications à long terme, déjà constatées, de la productivité des forêts françaises, Rev. For. Fr. LII numéro special: 37-48.

Dobbertin M., 2005. Tree growth as indicator of tree vitality and of tree reaction to environmental stress: a review. Eur. J. For. Res. 124: 319333.

Esper J., Cook E.R., Krusic P.J., Peters K., and Schweingruber F.H., 2003. Tests of the RCS method for preserving low frequency variability in long tree-ring chronologies. Tree-ring Res. 59: 81-98.

Fritts H.C., 1976. Tree ring and climate, Academic Press, New York, $567 \mathrm{p}$.

Graybill D.A. and Idso S.B., 1993. Detecting the aerial fertilization effect of atmospheric $\mathrm{CO}_{2}$ enrichment in tree-ring chronologies. Glob. Biogeochem. Cycles 7: 81-95.

Guiot J. and Goeury C., 1996. PPPBase, a software for statistical analysis of paleoecological and paleoclimatological data, Dendrochronologia 14: 295-300.

IPCC, Climate Change 1995a. The Science of Climate Change. Cambridge University Press, Cambridge, 572 p.

IPCC, Climate Change 1995b. Impacts, Adaptations and Mitigation of Climate Change: Scientific-Technical Analyses. Cambridge University Press, Cambridge, 878 p.

INERIS, 2004. Effet des dépôts atmosphériques de soufre et d'azote sur les sols et les eaux douces en France, Ministère de l'écologie et du Développement Durable, Paris. 116 p. 
Jarvis P.G., 1998. European Forest and Global Change. Cambridge University Press, Cambridge, 380 p.

Jones P.D. and Moberg A., 2003. Hemispheric and large-scale surface air temperature variations: an extensive revision and an update to 2001. J. Clim. 16: 206-223.

Keller T., Guiot J., and Tessier L., 1997. Climatic effect of atmospheric $\mathrm{CO}_{2}$ doubling on radial tree-growth in southeastern France, J. Biogeogr. 24: 857-864.

Keller T., Edouard J.-L., Guibal F., Guiot J., Tessier L., and Vila B., 2000. Impact d'un scénario climatique de réchauffement global sur la croissance des arbres. C. R. Biol. 323, 10: 913-924.

Kienast F. and Luxmoore R.J., 1988. Tree ring analysis and conifer growth responses to increased atmospheric $\mathrm{CO}_{2}$ levels. Oecologia 76: $487-495$.

Kilpeläinen A., Peltola H., Ryyppö A., Sauvala K., Laitinen K., and Kellomäki S., 2003. Wood properties of Scots pines (Pinus sylvestris) grown at elevated temperature and carbon dioxide concentration. Tree Physiol. 23: 889-897.

LaMarche V.C. Jr., Graybill D.A., Fritts H.C., and Rose M.R., 1984. Increasing atmospheric carbon dioxide: Tree ring evidence for growth enhancement in natural vegetation. Science 225: 1019-1021.

Lebourgeois F., 2007. Climatic signal in annual growth variation of silver fir (Abies alba Mill.) and spruce (Picea abies Karst.) from the French Permanent Plot Network (RENECOFOR). Ann. For. Sci. 64: 333 343.

Lebourgeois F. and Becker M., 1996. Dendroécologie du pin laricio de Corse dans l'Ouest de la France. Évolution du potentiel de croissance au cours des dernières décennies. Ann. Sci. For. 53: 931-946.

Lebourgeois F., Granier A., and Bréda N., 2001. Une analyse des changements climatiques régionaux en France entre 1956 et 1997. Réflexions en terme de conséquences pour les écosystèmes forestiers. Ann. For. Sci. 58: 733-754.

Luterbacher J., Dietrich D., Xoplaki E., Grosjean M., and Wanner H., 2004. European seasonal and annual temperautre variability, trends and extreme since 1500. Science 303: 1499-1503.

Mackenzie A., 2005. Instant notes maths and stats for biologists (Instant Notes Series). Taylor and Francis (Ed.), London, 310 p.

Menzel A. and Fabian P., 1999. Growing season extended in Europe. Nature 397: 659.

Nicault A., 1999. Analyse de l'influence du climat sur les variations inter et intra-annuelles de la croissance radiale du pin d'Alep (Pinus halepensis Mill.) en Provence calcaire, Thèse, Université d'AixMarseille III, Marseille, 256 p.

Picard J.F., 1995. Évolution de la croissance radiale du hêtre dans les Vosges. Premiers résultats sur le versant lorrain. Ann. Sci. For. 52: $11-21$.

Quézel P. and Médail F., 2003. Écologie et biogéographie des forêts du bassin méditerranéen. Elsevier, Paris, 571 p.

Rathgeber C., Guiot J., Roche P., and Tessier L., 1999. Augmentation de productivité du chêne pubescent en région méditerranéenne française. Ann. For. Sci. $56: 211-219$.
Rathgeber C., Nicault A., Guiot J., Keller T., Guibal F., and Roche P., 2000. Simulated responses of Pinus halepensis forest productivity to climatic change and $\mathrm{CO}_{2}$ increase using a statistical model. Glob. Planetary Change 26: 405-421.

Rathgeber C., Nicault A., Kaplan J.O., and Guiot J., 2003. Using a biogeochemistry model in simulating forests productivity responses to climatic change and [CO2] increase: example of Pinus halepensis in Provence (south-east France), Ecol. Model. 166: 239-255.

Rathgeber C., Nicault A., and Guiot J., 2005. Évolution de la croissance radiale du pin d'Alep (Pinus halepensis Mill.) en Provence calcaire (sud-est de la France). Ecol. Mediterr. 31: 75-82.

Ripert C. and Vennetier M., 2005. Évaluer la potentialité forestière d'un site sans observer la flore. Présentation d'une méthode développée en région méditerranéenne calcaire. ONF, RDV techniques $\mathrm{N}^{\circ}$ 8: 15-22.

Serre F., 1976. Les rapports de la croissance et du climat chez le pin d'Alep (Pinus halepensis Mill.). I. Méthodes utilisées. L'activité cambiale et le climat, Oecol. Plant. 11, 2: 143-171. II. L'allongement des pousses et des aiguilles et le climat Discussion générale. Oecol. Plant. 11: 201-224.

Serre-Bachet F., 1982. Analyse dendroclimatologique comparée de quatre espèces de pins et du chêne pubescent dans la region de la Gardiole près Rians (Var, France), Ecologia Mediterranea VIII, 2: 167-183.

Spiecker H., Mielikäinen K., Köhl M., and Skovsgaard J.P., 1996. Growth trends in European forests: studies from 12 countries. European Forest Institute Research Report $\mathrm{N}^{\circ} 5$, Springer-Verlag, Heidelberg, $372 \mathrm{p}$.

Stokes M.A. and Smiley T.L., 1968. An introduction to tree-ring dating. Chicago, Univ. Chicago Press, 73 p.

Telewski F.W., 1995. Wind-induced physiological and developmental responses in trees. In: Coutts M.P., Grace J. (Eds.), Wind and trees. Cambridge University Press, Cambridge, pp. 237-263.

Tessier L., 1984. Dendroclimatologie et écologie de Pinus silvestris L. et Quercus pubescens Willd. dans le Sud-Est de la France. Thèse d'Etat, Université d'Aix-Marseille III, Marseille, 275 p.

Tessier L., 1986. Approche dendroclimatologique de l'écologie de Pinus silvestris L. et Ouercus pubescens Willd. Dans le Sud-Est de la France. Acta Oecol. 7: 339-355.

Vennetier M. and Hervé J.C., 1999. Short and long term evolution of Pinus halepensis (Mill.) height growth in Provence, and its consequences for timber production. In: Timo Karjaleinen T., Spiecker H., Laroussine O. (Eds.), Tree growth acceleration in Europe, Nancy, pp. 263-265.

Vitousek P.M., Mooney H.A., Lubchenco J., and Mellilo J.M., 1997. Human domination of earth's ecosystems. Science 277: 494-499

Walther G.R., 2003. Plants in a warmer world. Perspect. Plant Ecol. Evol. Syst. 6: 169-185.

Walther G.R., Post E., Convey P., Menzel A., Parmesan C., Beebee T.J., Fromentin J-M., Hoegh-Guldberg O., and Bairlein F., 2002. Ecological responses to recent climate change. Nature 416: 389-395.

Woodward F.I., 1987. Climate and plant distribution. Cambridge University Press, Cambridge, UK, 90 p. 